\title{
Analisis Sikap Konsumen Terhadap Susu Bubuk Berkalsium Tinggi Dengan Menggunakan Multiatribut Model dan Norma Subyektif Model
}

\author{
Amam $^{1 *}$, Zaenal Fanani ${ }^{2}$,Bambang Ali Nugroho ${ }^{3}$ \\ ${ }^{1}$ Program Magister Agribisnis Program Strudi Ilmu Ternak Fakultas Peternakan Universitas Brawijaya \\ ${ }^{2}$ Fakultas Peternakan Universitas Brawijaya \\ ${ }^{3}$ Fakultas Peternakan Universitas Brawijaya
}

\begin{abstract}
ABSTRAK
Penelitian ini bertujuan untuk menganalisis:1) sikap konsumen terhadap atribut susu merek Hilo dan Anlene, 2) sikap konsumen terhadap pengaruh lingkungan sosial pada keputusan pembelian susu merek Hilo dan Anlene, serta 3) perbedaan sikap konsumen terhadap atribut susu bubuk Hilo dan Anlene. Atribut yang digunakan meliputi: merek, rasa, label, harga dan promosi, sedangkan lingkungan sosial konsumen meliputi: anggota keluarga, orang lain dan tenaga penjual. Penentuan sampel menggunakan teknik snowballsampling. Analisis data yang digunakan yaitu multi-atribut model dan norma subyektif model dengan menggunakan analisis Fishbein dan uji jenjang bertanda Wilcoxon. Multi-atribut model untuk mengetahui sikap konsumen terhadap atribut susu bubuk tinggi kalsium yang terdiri dari skor kepercayaan (bi) dan skor evaluasi (ei), sedangkan norma subyektif model untuk mengetahui pengaruh lingkungan sosial konsumen terhadap keputusan pembelian susu bubuk tinggi kalsium yang terdiri dari nilai keyakinan (NBj) dan nilai motivasi (MCj). Hasil penelitian menyebutkan bahwa: 1) konsumen memiliki sikap positif terhadap atribut susu bubuk berkalsium tinggi merek Hilo dan Anlene, yaitu sebesar 4,93 dan 4,73; 2) lingkungan sosial mempengaruhi norma subyektif konsumen dalam melakukan pembelian susu merek Hilo dan Anlene, yaitu sebesar 2,13 dan 2,18; 3) ada perbedaan sikap konsumen pada atribut rasa (Anlene $>0,20$ Hilo), label (Anlene 0,29 $>$ Hilo) dan promosi (Anlene $<0,66$ Hilo), sedangkan pada atribut merek dan harga tidak ada perbedaan sikap konsumen.
\end{abstract}

Kata kunci : sikap, perilaku konsumen, atribut, analisis Fishbein.

\section{ABSTRACT}

This study aimed to analyze: 1) consumer attitudes on the brand attributes of Hilo and Anlene milk, 2) consumer attitudes on the social environmental influences on purchase decisions Hilo and Anlene brand milk, and 3) differences in consumer attitudes on attribute Hilo and Anlene milk powder. Attributes are used include: brand, flavor, labels, price and promotion, while the social environment of consumers include: family members, other people and salespeople. The samples using snowball sampling technique. Analysis of the data used is a multi-attribute model and the subjective norm models using Fishbein analysis and level test Wilcoxon signed. Multi-attribute models to determine consumer attitudes on the attributes of powdered milk is high in calcium which is composed of scores of believe (bi) and an scores of evaluation (ei), whereas subjective norm models to determine the influence of the social environment of consumers on the purchase decision of powdered milk is high in calcium which comprises the value confidence ( $\mathrm{NBj}$ ) and the value of motivation (MCj). The study says that: 1 ) the consumer has a positive attitude on the attributes of high calcium milk powder brands Hilo and Anlene, each 4.93 and $4.73 ; 2$ ) the social environment affects subjective norms consumers in the purchase of Hilo and Anlene brand milk, each 2.13 and 2.18; 3) there are differences in consumer attitudes on taste attributes (Anlene> 0.20 Hilo), label (Anlene $0.29>$ Hilo) and promotion (Anlene $<0.66$ Hilo), while on the attributes of the brand and the price there is no difference in consumer attitudes.

Keywords: attitude, consumer behavior, attributes, Fishbein analysis.

\section{PENDAHULUAN}

\section{Latar Belakang}

Perkembangan teknologi dan informasi menyebabkan kebutuhan dan keinginan konsumen beranekaragam. Kondisi pasar yang terus berkembang membuat perusahaan semakin kompetitif dalam melakukan persaingan bisnis, termasuk persaingan dalam hal industri pengolahan berbahan susu yang kemudian berkembang menjadi susu bubuk berkalsium tinggi.

Alamat Penulis:

Amam

Email : amam.rafael@gmail.com

Alamat : Ujungsemi Dusun III No. 707 RT 22 RW 06 Cirebon

Perilaku konsumen dipengaruhi oleh empat faktor utama, yaitu: 1) budaya yang terdiri dari: kultur, subkultur, dan kelas sosial, 2) sosial yang terdiri dari: kelompok acuan, keluarga, peran dan status, 3) kepribadian yang terdiri dari: usia dan tahap siklus hidup, pekerjaan, keadaan ekonomi, gaya hidup, kepribadian dan konsep diri, serta 4) kejiwaan yang terdiri dari: motivasi, persepsi, pengetahuan, keyakinan dan sikap [1].

Sikap mampu mempengaruhi seseorang mengambil keputusan dalam melakukan pembelian, sehingga sikap mempunyai arti penting dalam pembuatan keputusan pemasaran suatu perusahaan, dan dengan analisis tentang sikap konsumen, maka perusahaan mampu memprediksi pasar di masa yang akan datang [2]. Sikap terdiri dari sikap positif dan sikap negatif yang bisa berubah-ubah sesuai dengan 
informasi yang konsumen dapatkan. Sikap terbentuk dari nilai kepercayaan dan nilai evaluasi. Nilai kepercayaan adalah informasi yang konsumen ketahui sebelum melakukan pembelian dan konsumsi, sedangkan nilai evaluasi adalah hasil dari evaluasi informasi setelah konsumen melakukan pembelian dan konsumsi.

Sikap konsumen terhadap suatu produk terdiri dari atribut yang menempel pada suatu produk tersebut. Atribut produk meliputi merek, rasa, label, harga dan promosi [3].

Sikap juga dipengaruhi oleh norma subyektif konsumen, yaitu merupakan pengaruh dari lingkungan sosial konsumen dalam melakukan keputusan pembelian [4]. Norma subyektif terdiri dari nilai keyakinan dan nilai motivasi yang konsumen terima. Nilai keyakinan adalah kepercayaan bahwa lingkungan sosial konsumen berpengaruh terhadap keputusan pembelian, sedangkan nilai motivasi adalah hasil evaluasi dari keyakinan terhadap kepercayaan bahwa lingkungan sosial konsumen yang berpengaruh pada keputusan pembelian.

Sikap konsumen yang dipengaruhi oleh lingkungan sosial terbagi menjadi tiga komponen, yaitu anggota keluarga, orang lain dan tenaga penjual[5].

Penelitian dengan menggunakan multi-atribut model bermanfaat untuk memprediksi keinginan dan kebutuhan pasar di masa yang akan datang [6], sedangkan norma subyektif model bermanfaat untuk mengetahui sejauh mana pengaruh lingkungan sosial terhadap keputusan pembelian susu bubuk berkalsium tinggi, dengan demikian sikap konsumen terbentuk dari multi-atribut model dan norma subyektif model[7].

\section{Tujuan Penelitian}

Tujuan penelitian ialah untuk menganalisis: 1) sikap konsumen terhadap atribut susu bubuk berkalsium tinggi merek Hilo dan Anlene, 2) pengaruh lingkungan sosial terhadap norma subyektif konsumen dalam melakukan pembelian susu Hilo dan Anlene, serta 3) perbedaan sikap konsumen terhadap atribut susu Hilo dan Anlene.

\section{Manfaat Penelitian}

Hasil penelitian diharapkan bermanfaat untuk: 1) mengembangkan teori terdahulu [8] khususnya teori Fishbein (1963) yang berfokus pada sikap konsumen melalui multi-atribut model dan teori Ginter (1974) yang berfokus pada lingkungan sosial konsumen melalui norma subyektif model yang diaplikasikan dalam bidang agribisnis peternakan, dan 2) digunakan sebagai bahan kajian dan informasi yang dapat digunakan dan dipertimbangkan oleh perusahaan untuk merumuskan dan memperbaiki strategi pemasaran dalam rangka memenuhi kebutuhan dan kepuasan konsumen.

\section{METODE PENELITIAN}

Penelitian ini merupakan penelitian kualitatif dengan menggunakan model pendekatan Fishbein, yaitu untuk menentukan sikap konsumen yang terdiri dari skor kepercayaan dan skor evaluasi terhadap atribut susu Hilo dan Anlene. Rumus yang digunakan yaitu:

$$
\mathrm{Ao}=\sum_{i=1}^{n} b i e i
$$

dimana:

$$
\begin{aligned}
\text { Ao } & =\text { sikap terhadap obyek, } \\
B i \quad & =\text { kekuatan kepercayaan bahwa objek memiliki } \\
& \text { atribut } i, \\
\text { ei } & =\text { evaluasi mengenai atribut } i, \text { dan } \\
\mathrm{n} \quad & =\text { jumlah aribut yang menonjol. }
\end{aligned}
$$

Norma subyektif model yaitu untuk menentukan pengaruh lingkungan sosial terhadap pembelian susu Hilo dan Anlene yang terdiri dari nilai keyakinan dan motivasi yang diterima konsumen. Rumus yang digunakan yaitu:

$$
\mathrm{SN}=\sum_{j=1}^{m}(\mathrm{NBj})(\mathrm{MCj})
$$

dimana:

$$
\begin{array}{ll}
\mathrm{SN} & =\text { norma subyektif model, } \\
\mathrm{NB}_{\mathrm{j}} & =\text { keyakinan norma individu, } \\
\mathrm{NC}_{\mathrm{j}} & =\text { motivasi konsumen, dan } \\
\mathrm{M} & =\text { banyaknya referen yang relevan } .
\end{array}
$$

\section{Lokasi dan Waktu Penelitian}

Lokasi penelitian di Kota Malang, hal tersebut mengacu pada pertimbangan bahwa belanja susu oleh masyarakat Kota Malang mencapai Rp 26.000 per keluarga per bulan.Waktu penelitian dilaksanakan pada bulan Maret sampai dengan September 2015.

\section{Metode Penentuan Sampel}

Metode yang digunakan ialahmultistage sampling, yaitu pemilihan sampel secara bertahap untuk mendapatkan penyebaran populasi sampel secara merata, sehingga diharapkan bisa mewakili keseluruhan total sampel.Sampel menggunakan siswa SMA di Kota Malang, penentuan jumlah sampel menggunakan pendekatan sebagai berikut:

$$
n=\frac{x^{2} N P(1-P)}{d^{2}(N-1)+x^{2} P(1-P)}
$$

dimana keterangan rumus di atas ialah sebagai berikut:

$$
\begin{array}{ll}
\mathrm{n} & =\text { ukuran sampel } \\
\mathrm{N} & =\text { ukuran populasi } \\
\mathrm{p} & =\text { proporsi populasi } \\
\mathrm{d} & =\text { derajat ketelitian } \\
\mathrm{X}^{2} & =\text { nilai tabel } \mathrm{X}^{2}
\end{array}
$$$$
\text { (Krejcie-Morgan) }
$$ 
$\mathrm{n}=\frac{(2,70)(5.045)(0,5)(1-0,5)}{(0,10)^{2}(5.045-1)+(2,70) 0,5(1-0,5)}$

$\mathrm{n}=\frac{3.405,3}{51,115}$

$\mathrm{n}=67,62$

Berdasarkan teori perhitungan sampel KrejcieMorgan [9], maka ditentukan jumlah sampel sebanyak 80 responden, sehingga masing-masing 40 responden susu Hilo dan 40 responden susu Anlene.

\section{Definisi Operasional dan Pengukuran Variabel}

Atribut yang digunakan pada susu Hilo dan Anlene meliputi: merek, rasa, label, harga dan promosi [10].

a) Merek adalah nama, inisial atau kombinasi unsurunsur tersebut yang dirancang untuk mengidentifikasi suatu produk. Pengukurannya adalah terkenal, dengan indikator mudah diingat, mudah didapat, banyak diperbincangkan dan disukai masyarakat.

b) Rasaadalah kelengkapan rasa yang bisa dinikmati konsumen.Pengukurannya ialah enak, dengan indikator variasi rasa, kental, gurih, manis dan tidak amis.

c) Labeladalah bagian produk yang membawa informasi verbal tentang produk. Pengukurannya ialah menarik, dengan indikator pewarnaan kontras, gambar menarik, desain menarik, penggunaan kata berkesan dan jenis font yang digunakan menarik.

d) Harga adalah sejumlah uang yang akan diberikan kepada penjual (produsen) untuk mendapatkan sejumlah barang tertentu sesuai dengan perjanjian antara penjual dan pembeli. Harga merupakan kemampuan daya beli konsumen untuk mendapatkan dan mengkonsumsi susu bubuk berkalsium tinggi. Pengukuran harga yaitu kemampuan daya beli (murah-mahal), harga merek lain (pesaing), ekonomis, penggunaan diskon dan penetapan harga sesuai dengan manfaat yang dirasakan.

e) Promosi adalah media untuk memperkenalkan suatu produk (barang atau jasa) kepada masyarakat. Bentuk promosi bisa melalui visual, audio dan audio-visual.Pengukurannya mengena/berkesan, dengan indikator sering muncul di media, penyampaian pesan informatif, jangkauan promosi luas, kualitas penyampaian pesan yang menarik dan mudah untuk mengingat merek produk.

Variabel keyakinan normatif terdiri dari keyakinan dan motivasi dari lingkungan sosial responden yang meliputi: anggota keluarga, orang lain dan tenaga penjual [11].

a) Keluarga, adalah dua orang atau lebih yang tinggal bersama karena ada ikatan perkawinan atau hubungan darah yang dapat memberikan pengaruh dan motivasi terhadap pembelian, pengukurannya ialah pemberian informasi, pemberian rekomendasi, pemberian penawaran, pemberian saran dan pemberian ajakan untuk mengkonsumsi.

b) Orang lain, adalah orang yang dikenal (teman maupun relasi) atau tidak dikenal (orang asing) yang telah memberikan informasi tentang produk, pengukurannya ialah pemberian informasi, pemberian rekomendasi, pemberian penawaran, pemberian saran dan pemberian ajakan untuk mengkonsumsi [12].

c) Tenaga penjual, adalah orang yang menjual atau menawarkan produknya kepada responden, pengukurannya ialah pemberian informasi, pemberian rekomendasi, pemberian penawaran, pemberian saran dan pemberian ajakan untuk mengkonsumsi.

\section{Metode Pengumpulan Data}

a) Responden diminta menanggapi masing-masing atribut susu bubuk dengan ketentuan:

$\begin{array}{ll}\text { sangat percaya } & \text { skor }+2 \\ \text { percaya } & \text { skor }+1 \\ \text { netral } & \text { skor } 0 \\ \text { tidak percaya } & \text { skor }-1 \\ \text { sangat tidak percaya } & \text { skor }-2\end{array}$

b) Responden diminta mengevaluasi masing-masing atribut susu bubuk dengan ketentuan:

$\begin{array}{ll}\text { sangat percaya } & \text { skor }+2 \\ \text { percaya } & \text { skor }+1 \\ \text { netral } & \text { skor } 0 \\ \text { tidak percaya } & \text { skor }-1 \\ \text { sangat tidak percaya } & \text { skor }-2\end{array}$

c) Responden diminta mengisi kuisioner norma subyektif model yaitu keyakinan dan motivasi dari lingkungan sosial yang mempengaruhi konsumen dalam melakukan pembelian susu Hilo dan Anlene dengan ketentuan:

$\begin{array}{ll}\text { sangat setuju } & \text { skor }+2 \\ \text { setuju } & \text { skor }+1 \\ \text { netral } & \text { skor } 0 \\ \text { tidak setuju } & \text { skor }-1 \\ \text { sangat tidak setuju } & \text { skor }-2\end{array}$

\section{Penilaian Responden}

Pembentukan interval kelas dengan rumus:

$$
\begin{aligned}
& =\frac{\text { skor tertinggi }- \text { skor terendah }}{\text { jumlah kelas }} \\
& =\frac{+2-(-2)}{5}=\frac{4}{5}=0,8
\end{aligned}
$$

Berdasarkan perhitungan interval kelas, maka didapatkan skor penilaian sebagai berikut:
a) skor sangat rendah : $-2 \mathrm{~s} / \mathrm{d}-1,2$
b) skor rendah $\quad:-1,19 \mathrm{~s} / \mathrm{d}-0,4$
c) skor sedang : :-0,39 s/d 0,4 

d) skor tinggi
$: 0,4 \mathrm{~s} / \mathrm{d} 1,2$
e) skor sangat tinggi
: $1,21 \mathrm{~s} / \mathrm{d} 2$

\section{PEMBAHASAN}

\section{Gambaran Umum Penelitian}

Produk yang menjadi obyek penelitian adalah produk susu bubuk berkalsium tinggi merek Hilo dan Anlene dengan atribut merek, rasa, label, harga dan promosi yang diberi skor $+2,+1,0,-1$, dan -2 , untuk kategori sangat percaya, percaya, netral, tidak percaya dan sangat tidak percaya [13].

Penelitian multi-atribut model dimana konsumen diminta untuk memberikan tanggapan sebelum dan sesudah mengkonsumsi susu Hilo dan Anlene. Tanggapan konsumen sebelum melakukan konsumsi disebut dengan skor kepercayaan (believe score), sedangkan tanggapan konsumen setelah melakukan konsumsi disebut dengan skor evaluasi (evaluation score).

Penelitian norma subyektif model yang berkaitan dengan orang lain (referensi) yang dapat mempengaruhi pembelian konsumen. Pengaruh orang lain dalam penelitian ini meliputi anggota keluarga, orang lain dan tenaga penjual [14].

Analisis norma subyektif diketahui dengan cara responden diminta untuk memberikan nilai keyakinan dan nilai motivasi dengan memberikan skor $+2,+1,0$, 1 , dan -2 untuk kategori sangat setuju, setuju, netral, tidak setuju dan sangat tidak setuju [15].

\section{Profil Produk}

Susu bubuk Hilo diproduksi oleh PT Nutrifood Raya yang berlokasi di Ciawi-Bogor. Susu Hilo merupakan susu yang memiliki label top brand pada tahun 2014. Komposisi pada susu bubuk Hilo terdiri dari skim, gula pasir, maltodekstrin, krimmer nabati, susu bubuk full krim, premix vitamin dan mineral, perisa artificial, vanilla, alga merah, kolin, kromium pikolinat dan perisa karamel.

Susu bubuk Anlene diproduksi oleh PT Tigaraksa Satria, Tbk untuk PT Fonterra Brands yang berlokasi di Jakarta. Komposisi susu Anlene terdiri dari susu bubuk tanpa lemak, maltodekstrin, bubuk whey, susu bubuk, campuran fostrunan-inulin dengan DP minimum 10, kalsium karbonat, premix mineral dan vitamin D.

\section{Profil Konsumen}

Responden terdiri dari 40 konsumen susu bubuk tinggi kalsium merek Hilo dan 40 merek Anlene. Profil konsumen dalam penelitian ini meliputi: 1) jenis kelamin, 2) konsumsi harian dan 3) lama konsumsi [16].

\section{Jenis Kelamin}

Hasil penelitian menunjukkan bahwa konsumen susu Hilo terdiri dari 29 laki-laki dan 11 perempuan, sedangkan konsumen susu Anlene terdiri dari 17 laki- laki dan 23 perempuan. Hal tersebut menunjukkan bahwa laki-laki lebih memilih produk susu bubuk Hilo dan perempuan lebih memilih produk susu bubuk Anlene [17].

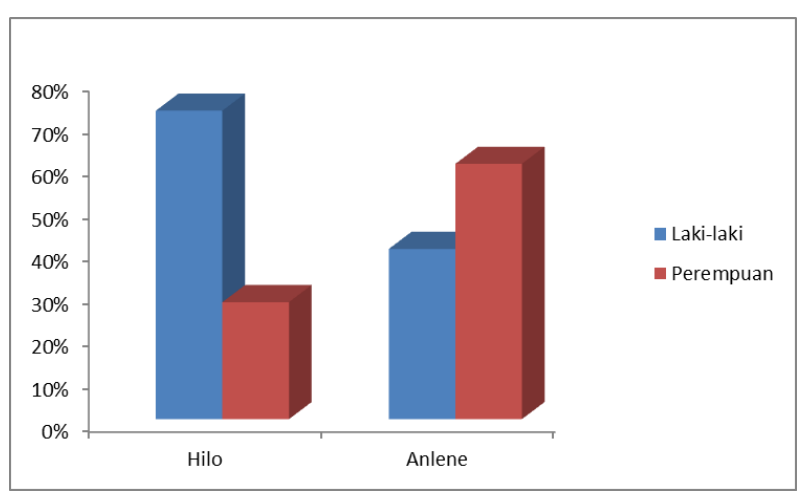

Grafik 1. Perbandingan Jenis Kelamin Berdasarkan Konsumen Susu Bubuk

Grafik 1 menjelaskan bahwa konsumen susu bubuk Merek Hilo untuk kategori laki-laki sebesar $72,50 \%$ dan perempuan sebesar 27,50\%, sedangkan susu bubuk Merek Anlene untuk kategori laki-laki sebesar $40 \%$ dan perempuan sebesar $60 \%$.

\section{Konsumsi Harian}

Konsumsi harian merupakan intensitas kebutuhan atau keinginan pembeli dalam mengkonsumsi susu bubuk berkalsium tinggi tiap harinya. Konsumsi harian dibagi menjadi empat kategori, yaitu $1 x /$ hari, $2 x /$ hari, $3 x /$ hari dan $>3 x /$ hari. Konsumsi harian merupakan salah satu dari perilaku konsumen dalam menghabiskan suatu produk kemudian memutuskan akan melakukan pembelian lagi atau mengganti dengan produk merek lain atau bahkan memutuskan untuk tidak mengkonsumsi lagi.

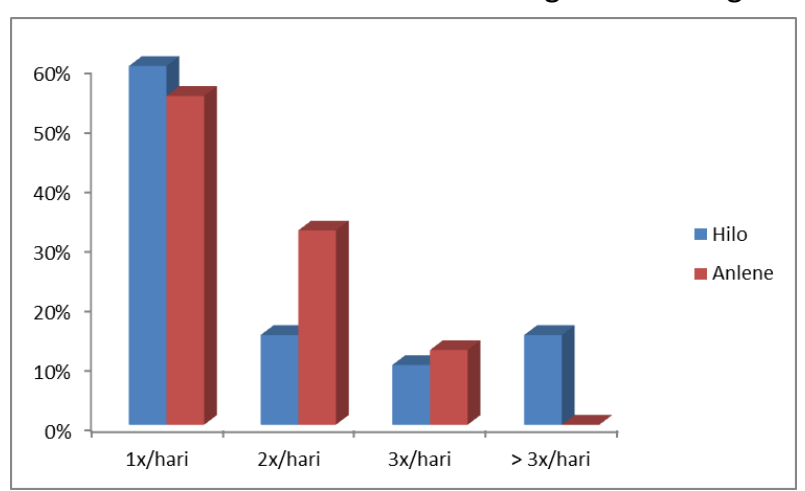

Grafik 2.Konsumsi Harian Berdasarkan Konsumen Susu Bubuk

Konsumsi harian pada susu bubuk merek Hilo berurut-urut ialah $1 x /$ hari sebanyak 24 responden (60\%), 2x/hari sebanyak 6 responden $(15 \%), 3 x /$ hari sebanyak 4 responden (10\%) dan $>3 x /$ hari sebanyak 6 responden (15\%). Konsumsi harian pada susu bubuk merek Anlene berurut-urut ialah $1 x$ /hari sebanyak 22 responden $(55 \%), 2 x /$ hari sebanyak 13 responden 
$(32,50 \%), 3 x /$ hari sebanyak 5 responden $(12,50 \%)$, sedangkan untuk konsumsi harian $>3 x$ /hari tidak ada.

\section{Lama Konsumsi}

Lama konsumsi suatu produk merupakan salah satu perilaku konsumen. Lama konsumsi bisa dijadikan indikator loyalitas konsumen terhadap suatu merek tertentu. Lamanya konsumen dalam mengkonsumsi bisa dilihat pada tabel berikut ini:

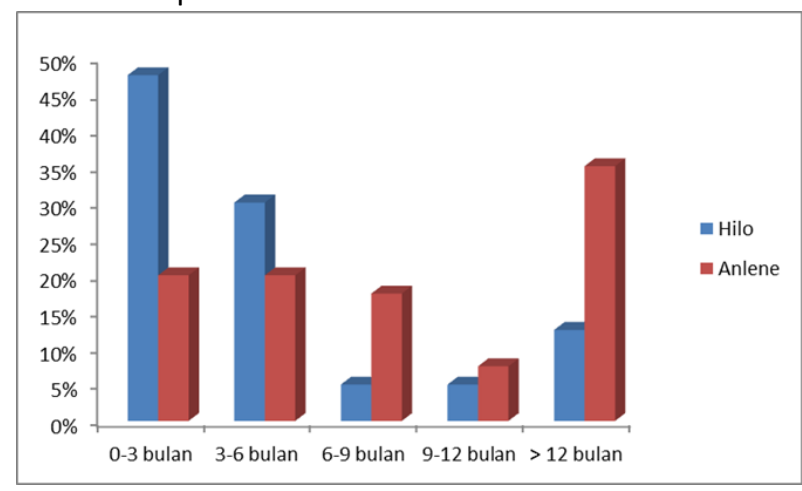

Grafik 3. Lama Konsumsi Berdasarkan Konsumen Susu Bubuk

Lama konsumsi konsumen terhadap susu Hilo berurut-urut ialah 19 responden (47,5\%), 12 responden (30\%), 2 responden (5\%), 2 responden (5\%) dan 5 responden (12,5\%). Lama konsumsi konsumen terhadap susu Anlene berurut-urut ialah 8 responden (20\%), 8 responden $(20 \%), 7$ responden $(17,5 \%), 3$ responden $(7,5 \%)$ dan 14 responden (35\%).Konsumsi terbanyak susu Hilo yaitu pada bulan pertama hingga bulan ketiga, sedangkan konsumsi terbanyak susu Anlene yaitu lebih dari satu tahun.

\section{Perilaku Konsumen}

\section{Faktor yang sering Menjadi Pertimbangan dalam} Pembelian Produk

Terdapat banyak faktor yang dapat melatarbelakangi konsumen dalam memilih jenis produk susu bubuk, dari banyak faktor tersebut terdapat beberapa faktor yang sering menjadi pertimbangan dalam memilih susu bubuk sebagaimana penjelasan di bawah ini:

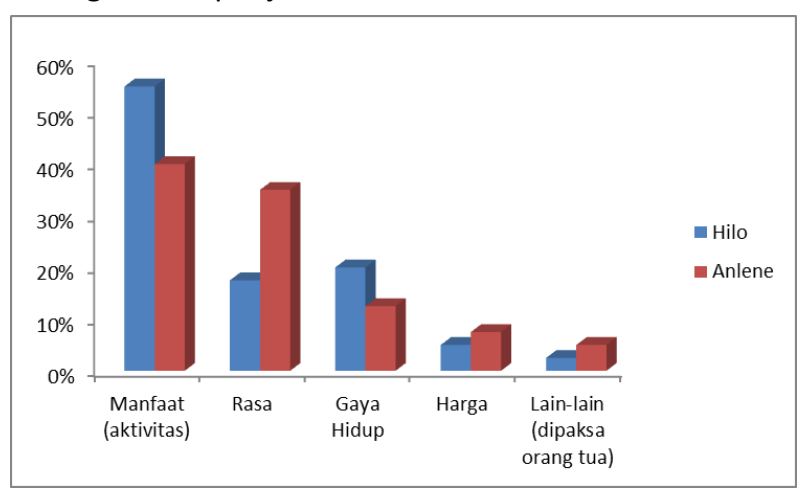

Grafik 4.Faktor yang sering Menjadi Pertimbangan Konsumen

Pertimbangan manfaat ialah untuk aktivitas dan pertumbuhan, sedangkan lain-lain merupakan paksaan dari orang tua [18].
Faktor yang menjadi pertimbangan konsumen untuk susu Hilo secara berurut-urut ialah 22 responden $\quad(55 \%), \quad 7 \quad$ responden(17,5\%), 8 responden(20\%), 2 responden(5\%) dan 1 responden (2,5\%). Faktor yang menjadi pertimbangan konsumen untuk Anlene secara berurut-urut ialah 16 responden (40\%), 14 responden (35\%), 5 responden(12,5\%), 3 responden(7,5\%) dan 2 responden(5\%).

Faktor yang paling dominan konsumen dalam melakukan pertimbangan konsumsi pada susu Hilo dan Anlene ialah faktor manfaat, yaitu masing-masing sebesar $55 \%$ dan $40 \%$.

\section{Tingkat Kepentingan Atribut}

Atribut susu bubuk yang dijadikan pertimbangan dalam penelitian meliputi: 1) merek, 2) rasa, 3) label, 4) harga dan5) promosi [19]. Atribut tersebut kemudian dirangking tingkat kepentingannya oleh responden menurut pertimbangannya masingmasing [20]. Perangkingan tersebut dilakukan dengan cara memberi penilaian dari satu sampai lima berdasarkan tingkat kepentingan yang dirasakan oleh responden [21], sebagaimana ditunjukkan dalam tabel di bawah ini:

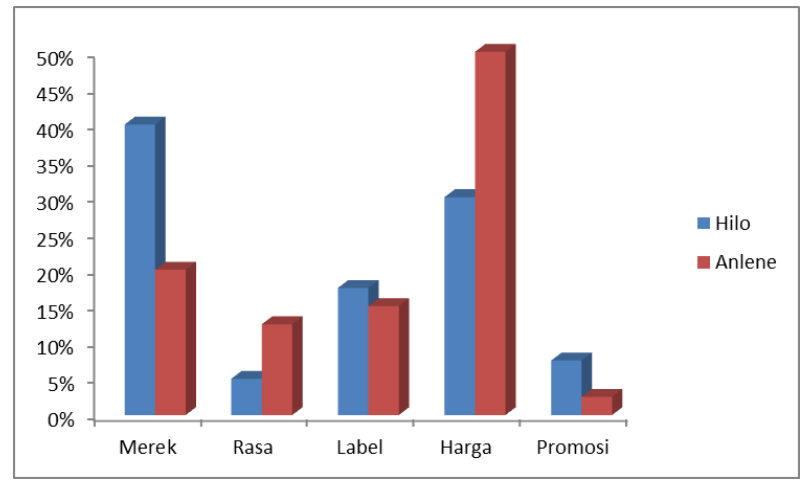

Grafik 5.Tingkat Kepentingan Atribut Menurut Konsumen

Tingkat kepentingan atribut menurut konsumen pada susu Hilo dan Anlene terdiri dari atribut merek, rasa, label, harga dan promosi. Tingkat kepentingan atribut susu Hilo menurut konsumen secara berurutan ialah 12 responden(30\%), 16 responden(40\%), 7 responden $(17,5 \%), \quad 2$ responden(5\%) dan 3 responden(7,5\%). Tingkat kepentingan atribut susu Anlene menurut konsumen secara berurutan ialah 20 responden(50\%), 8 responden(20\%), $6 \quad$ responden(15\%),5 responden(12,5\%) dan 1 responden $(2,5)$.

Tingkat kepentingan atribut tertinggi menurut konsumen susu Hilo ialah mereknya, sedangkan menurut konsumen susu Anlene ialah harganya. Hal tersebut didukung oleh label top brands yang dimiliki Hilo sehingga konsumen memilih Hilo karena mereknya, sedangkan harga susu Anlene lebih murah dibandingkan susu Hilo dengan selisih Rp 51.000 per kilogram sehingga konsumen memilih susu Anlene karena harganya.

\section{Analisis Multi-Atribut Model}




\section{Menentukan Skor Kepercayaan (Bi)}

Tingkat kepercayaan konsumen terhadap atribut produk susu bubuk berkalsium tinggi diperoleh dengan cara konsumen diminta pendapatnya mengenai atribut merek, rasa, label, harga dan promosi ketika sebelum menggunakan merek tersebut, baik mereka mendapatkan informasi yang komplit, sebagian atau sedikit tentang merek tersebut.

Tabel 1. Skor Kepercayaan Konsumen

\begin{tabular}{lcclccl}
\hline Atribut & \multicolumn{3}{l}{ Hilo } & \multicolumn{4}{c}{ Anlene } \\
\hline & $\sum$ & Skor & Kategori & $\sum$ & Skor & Kategori \\
\hline Merek & 44 & 1,10 & terkenal & 40 & 1,00 & terkenal \\
Rasa & 34 & 0,85 & enak & 36 & 0,90 & enak \\
Label & 39 & 0,98 & menarik & 39 & 0,98 & menarik \\
Harga & 44 & 1,10 & mahal & 45 & 1,13 & mahal \\
Promosi & 38 & 0,95 & mengena & 16 & 0,40 & $\begin{array}{l}\text { cukup } \\
\text { mengena }\end{array}$ \\
\hline
\end{tabular}

Sumber: Data Primer (diolah)

\section{Menentukan Skor Evaluasi (Ei)}

Skor evaluasi konsumen terhadap produk susu bubuk berkalsium tinggi merek Hilo dan Anlene diperoleh dengan cara konsumen diminta untuk memberikan penilaian terhadap atribut produk yang benar-benar mereka terima (rasakan) setelah membeli dan menggunakan susu bubuk merek tersebut.

Tabel 2. Skor Evaluasi Konsumen

\begin{tabular}{lclllll}
\hline Atribut & \multicolumn{2}{l}{ Hilo } & \multicolumn{4}{c}{ Anlene } \\
\hline & $\sum$ & Skor & Kategori & $\sum$ & Skor & Kategori \\
\hline Merek & 41 & 1,03 & terkenal & 37 & 0.93 & terkenal \\
Rasa & 35 & 0,88 & Enak & 42 & 1,05 & enak \\
Label & 40 & 1,00 & menarik & 52 & 1,30 & menarik \\
Harga & 43 & 1,08 & mahal & 48 & 1,20 & mahal \\
Promosi & 37 & 0,93 & mengena & 22 & 0,55 & mengena \\
\hline
\end{tabular}

Sumber: Data Primer (diolah)

\section{Menentukan Sikap Konsumen (Ao)}

Berdasarkan hasil yang diperoleh dari tingkat kepercayaan dan tingkat evaluasi konsumen terhadap atribut-atribut yang sama pada merek susu bubuk yang berbeda, maka dapat diukur sikap konsumen terhadap produk susu merek Hilo dan susu merek Anlene dengan cara mengalikan skor kepercayaan dengan skor evaluasi melalui pendekatan Fishbein.

Tabel 3.Analisis Multi-Atribut Model

\begin{tabular}{lllllll}
\hline \multirow{2}{*}{ Atribut } & \multicolumn{3}{c}{ Hilo } & \multicolumn{3}{c}{ Anlene } \\
\cline { 2 - 7 } & $\mathrm{Ei}$ & $\mathrm{Bi}$ & $\mathrm{Ao}$ & $\mathrm{Ei}$ & $\mathrm{Bi}$ & $\mathrm{Ao}$ \\
\hline Merek & 1,03 & 1,10 & 1,13 & 0,93 & 1,00 & 0,93 \\
Rasa & 0,88 & 0,85 & 0,75 & 1,05 & 0,90 & 0,95 \\
Label & 1,00 & 0,98 & 0,98 & 1,30 & 0,98 & 1,27
\end{tabular}

\begin{tabular}{ccccccc} 
Harga & 1,08 & 1,10 & 1,19 & 1,20 & 1,13 & 1,36 \\
Promosi & 0,93 & 0,95 & 0,88 & 0,55 & 0,40 & 0,22 \\
\hline \multicolumn{1}{c}{ Skor } & & 4,93 & & & 4,73 & \\
\hline
\end{tabular}

Sumber: Data Primer (diolah)

Berdasarkan tabel 3 diperoleh hasil bahwa produk susu bubuk merek Hilo memiliki skor sebesar 4,93, dan skor tersebut lebih besar dari pada susu bubuk merek Anlene yang memiliki skor 4,73. Hal tersebut menunjukkan bahwa produk susu bubuk merek Hilo lebih mendekati harapan dari responden dibandingkan dengan produk susu bubuk merek Anlene.

Sikap konsumen pada masing-masing atribut susu Hilo secara berurutan ialah merek sebesar 1,13, harga sebesar 1,10 , label sebesar 0,98 , promosi sebesar 0,95 dan rasa sebesar 0,85. Sikap konsumen pada masing-masing atribut susu Anlene secara berurutan ialah harga sebesar 1,36, label sebesar 1,27, rasa sebesar 0,95, merek sebesar 0,93 dan promosi sebesar 0,22.

Hasil analisis Fishbein pada sikap konsumen terhadap susu bubuk Merek Hilo dan Anlene masingmasing sebesar 4,93 dan 4,73. Hal tersebut menunjukkan hasil (angka) positif, sehingga hasil analisis Fishbein di atas membuktikan bahwa sikap konsumen terhadap atribut susu bubuk Hilo dan Anlene juga positif.

\section{Analisis Norma Subyektif Model 1. Menentukan Nilai Keyakinan (NBj)}

Cara memperoleh norma subyektif konsumen (SN) yaitu pertama-tama adalah mencari nilai keyakinan. Nilai keyakinan konsumen diperoleh dengan cara konsumen diminta pendapatnya mengenai keyakinan bahwa orang lain (lingkungan sosial) mempunyai pengaruh terhadap keputusan pembelian susu bubuk berkalsium tinggi.

Tabel 4. Nilai Keyakinan Konsumen

\begin{tabular}{lcccc}
\hline \multirow{2}{*}{$\begin{array}{c}\text { Variabel } \\
\text { lingkungan Sosial }\end{array}$ Konsumen } & \multicolumn{2}{c}{ Hilo } & \multicolumn{2}{c}{ Anlene } \\
\cline { 2 - 5 } & $\sum$ & Skor & $\sum$ & Skor \\
\hline Anggota keluarga & 47 & 1,18 & 40 & 1,00 \\
Orang lain & 20 & 0,50 & 26 & 0,65 \\
Tenaga penjual & 28 & 0,70 & 33 & 0,83 \\
\hline Sumber:
\end{tabular}

Sumber: Data Primer (diolah)

\section{Menentukan Nilai Motivasi (NCj)}

Nilai motivasi individu konsumen diperoleh dengan cara konsumen diminta pendapatnya mengenai motivasi yang diterimanya dari orang lain (referen) atau lingkungan sosialnya yang berkaitan dengan keputusan pembelian susu bubuk berkalisum tinggi merek Hilo atau merek Anlene.

Tabel 5. Nilai Motivasi Konsumen 


\begin{tabular}{lcccc}
\hline \multirow{2}{*}{$\begin{array}{l}\text { Variabel } \\
\text { lingkungan Sosial } \\
\text { Konsumen }\end{array}$} & \multicolumn{2}{c}{ Hilo } & \multicolumn{2}{c}{ Anlene } \\
\cline { 2 - 5 } & $\Sigma$ & Skor & $\sum$ & Skor \\
\hline Anggota keluarga & 44 & 1,10 & 39 & 0,98 \\
Orang lain & 22 & 0,55 & 29 & 0,73 \\
Tenaga penjual & 32 & 0,80 & 35 & 0,88 \\
\hline
\end{tabular}

Sumber: Data Primer (diolah)

\section{Menentukan Norma Subyektif (SN)}

Menentukan norma subyektif konsumen dapat diketahui dengan cara mengalikan nilai skor kayakinan dengan skor motivasi.

Tabel 6. AnalisisNorma Subyektif Model

\begin{tabular}{lllllll}
\hline $\begin{array}{c}\text { Variabel } \\
\text { lingkungan Sosial } \\
\text { Konsumen }\end{array}$ & Hilo & & \multicolumn{4}{c}{ Anlene } \\
\cline { 2 - 7 } & $\mathrm{NCj}$ & $\mathrm{NBj}$ & $\mathrm{SN}$ & $\mathrm{NCj}$ & $\mathrm{NBj}$ & $\mathrm{SN}$ \\
\hline Anggota keluarga & 1,10 & 1,18 & 1,30 & 0,98 & 1,00 & 0,98 \\
Orang lain & 0,55 & 0,50 & 0,28 & 0,73 & 0,65 & 0,47 \\
Tenaga penjual & 0,80 & 0,70 & 0,56 & 0,88 & 0,83 & 0,73 \\
\hline \multicolumn{1}{c}{ Skor } & 2,13 & & & & 2,18 & \\
\hline
\end{tabular}

Sumber: Data Primer (diolah)

Berdasarkan Tabel 6 melalui analisis Fishbein didapatkan skor norma subyektif model pada susu bubuk Hilo sebesar 2,13, nilai tersebut lebih kecil dari pada susu bubuk Anlene sebesar 2,18. Hal tersebut mengarah pada suatu hasil analisa pada atribut susu Anlene yang mempunyai nilai terendah yaitu promosi, oleh sebab itu para responden memilih mengkonsumsi susu Anlene karena faktor keyakinan dan motivasi (referen) yang diterimanya dari lingkungan sosial yang meliputi anggota keluarga, orang lain dan tenaga penjual.

Analisis norma subyektif model pada susu Hilo ialah anggota keluarga sebesar 1,30 , orang lain sebesar 0,28 dan tenaga penjual sebesar 0,56. Analisis norma subyektif model pada susu Anlene ialah anggota keluarga sebesar 0,98 , orang lain sebesar 0,47 dan tenaga penjual sebesar 0,73 .

Hasil analisis Fishbein pada norma subyektif model konsumen dalam melakukan pembelian susu bubuk Hilo dan Anlene masing-masing sebesar 2,13 dan 2,18, hal tersebut menunjukkan bahwa norma subyektif memiliki hasil (angka) positif. Hasil analisis Fishbein diatas membuktikan bahwa lingkungan sosial berpengaruh positif terhadap keputusan pembelian dan konsumsi susu bubuk Hilo dan Anlene.

\section{Perbedaan Sikap Konsumen}

Perbedaan sikapdigunakan untuk membandingkan perbedaan sikap konsumen pada masing-masing atribut susu bubuk merek Hilo dan Anlene. Perbandingan tersebut bertujuan untuk mengetahui keunggulan dan kelemahan dari masingmasing atribut yang melekat pada kedua susu bubuk, sehingga bisa digunakan sebagai bahan evaluasi berdasarkan sikap konsumen di masa yang akan datang.

Perbedaan tersebut dianalisis menggunakan uji Wilcoxon dengan hasil sebagai berikut:

Tabel 7. Hasil Uji Wilcoxon terhadap Perbedaan Sikap Konsumen

\begin{tabular}{|c|c|c|c|c|c|c|c|c|c|}
\hline \multirow{3}{*}{ Atribut } & \multirow{2}{*}{\multicolumn{2}{|c|}{ Beda }} & \multirow{2}{*}{\multicolumn{2}{|c|}{ Peringkat }} & \multicolumn{4}{|c|}{ Tanda Peringkat } & \multirow{3}{*}{ Keterangan } \\
\hline & & & & & \multicolumn{2}{|c|}{ Hilo } & \multicolumn{2}{|c|}{ Anlene } & \\
\hline & Hilo & Anlene & Hilo & Anlene & + & - & + & - & \\
\hline Merek & -3 & -3 & -6 & -6 & & -6 & & -6 & Tidak Berbeda \\
\hline Rasa & 1 & 6 & 2,5 & 8,5 & 2,5 & & 8,5 & & Berbeda \\
\hline Label & 1 & 13 & 2,5 & 10 & 2,5 & & 10 & & Berbeda \\
\hline Harga & -1 & 3 & $-2,5$ & 6 & & $-2,5$ & 6 & & Tidak Berbeda \\
\hline Promosi & -1 & 6 & $-2,5$ & 8,5 & & $-2,5$ & 8,5 & & Berbeda \\
\hline
\end{tabular}

Berdasarkan hasil perhitungan (tanpa memperhatikan tanda), maka hasil tanda peringkat pada susu bubuk Hilo dan Anlene saling dibandingkan dengan hasil nilai $t$ tabel. Penarikan kesimpulan pada uji Wilcoxon yaitu apabila $t$ hitung lebih kecil daripada $t$ tabel, maka keputusannya adalah menolak $\mathrm{H}_{0}$. Hasil uji Wilcoxon menunjukkan bahwa sikap konsumen terhadap atribut merek dan Harga susu bubuk Hilo dan Anlene yaitu tidak berbeda, sedangkan sikap konsumen terhadap atribut rasa, label dan promosi susu bubuk Hilo dan Anlene yaitu berbeda.

Perbedaan sikap konsumen terhadap atribut rasa susu Hilo dan Anlene juga didukung oleh analisis Fishbein yang menunjukkan bahwa sikap konsumen - 
terhadap rasa susu Hilo sebesar 0,75 sedangkan Anlene sebesar 0,95. Hal tersebut menunjukkan bahwa terdapat selisih sikap konsumen dimana sikap konsumen pada atribut rasa susu Anlene lebih tinggi dibandingkan susu Hilo sebesar 0,20.

Perbedaan sikap konsumen terhadap atribut label susu Hilo dan Anlene juga didukung oleh analisis Fishbein yang menunjukkan bahwa sikap konsumen terhadap label kemasan susu Hilo sebesar 0,98 ,sedangkan Anlene sebesar 1,27. Hal tersebut menunjukkan bahwa terdapat selisih sikap konsumen dimana sikap konsumen pada atribut label susu Anlene lebih tinggi dibandingkan susu Hilo sebesar 0,29 .

Perbedaan sikap konsumen terhadap atribut promosi susu Hilo dan Anlene juga didukung oleh analisis Fishbein yang menunjukkan bahwa sikap konsumen terhadap promosi susu Hilo sebesar 0,88 sedangkan Anlene sebesar 0,22. Hal tersebut menunjukkan bahwa terdapat selisih sikap konsumen dimana sikap konsumen pada atribut promosi susu Hilo lebih tinggi dibandingkan susu Anlene sebesar 0,66 . Rendahnya atribut susu Anlene menurut sikap konsumen juga dibuktikan oleh tingginya nilai angka subyektif model sebesar 2,18 dibandingkan susu Hilo sebesar 2,13. Artinya bahwa pembelian produk susu Anlene dipengaruhi oleh lingkungan sosial konsumen.

\section{Implikasi}

\section{Implikasi pada Merek}

Hasil penelitian mengenai sikap konsumen pada atribut merek susu bubuk Hilo dan Anlene masing-masing sebesar 1,13 dan 0,93. Sikap konsumen pada atribut merek Hilo lebih kuat dibandingkan merek Anlene, yaitu selisih 0,2. Berdasarkan hasil uji Wilcoxon, meskipun sikap kosumen terhadap atribut merek Hilo lebih tinggi 0,2 dibandingkan dengan merek Anlene, namun sikap konsumen terhadap merek tersebut tidak memiliki perbedaan (dengan tanda peringkat masing-masing-6), sedangkan pada analisis Fishbein sikap konsumen pada merek Hilo lebih tinggi dibanding Anlene, hal tersebut juga didukung oleh label Top Brands yang diraih Hilo pada tahun 2014.

\section{Implikasi pada Rasa}

Hasil penelitian mengenai sikap konsumen pada atribut rasa susu bubuk Hilo dan Anlene masingmasing sebesar 0,75 dan 0,95. Sikap konsumen pada atribut rasa Anlene lebih kuat dibandingkan merek Hilo, hal tersebut disebabkan karena konsumen menilai bahwa susu Anlene memiliki cita rasa yang lebih enak, lebih kental dan lebih gurih. Perbedaan sikap konsumen diperkuat oleh hasil uji Wilcoxon yang menyebutkan bahwa sikap konsumen terhadap atribut rasa susu bubuk Hilo dan Anlene berbeda, yaitu masing-masing 2,5 dan 8,5.

Perbedaan sikap konsumen pada kedua rasa susu bubuk juga dibuktikan oleh lamanya konsumsi susu bubuk oleh konsumen melebihi waktu satu tahun yaitu masing-masing Anlene sebesar 35\% dan Hilo sebesar $12,5 \%$. Hal tersebut mengindikasikan bahwa tingkat loyalitas konsumen terhadap rasa susu Anlene lebih tinggi dari pada rasa susu Hilo.

Berdasarkan pada kondisi tersebut salah satu strategi yang dapat dilakukan perusahaan Hilo adalah membuat inovasi baru pada produk untuk mempunyai rasa yang lebih kuat, sehingga konsumen memiliki sikap yang lebih positif terhadap atribut rasa yang dimiliki susu Hilo.

\section{Implikasi pada Label}

Hasil penelitian mengenai sikap konsumen pada atribut label susu bubuk Hilo dan Anlene masingmasing sebesar 0,98 dan 1,27. Sikap konsumen pada atribut label Anlene lebih kuat dibandingkan merek Hilo, hal tersebut disebabkan karena label yang dimiliki produk Anlene lebih menarik dibandingkan produk Hilo. Hasil uji Wilcoxon menyebutkan bahwa sikap konsumen terhadap atribut label susu bubuk Hilo dan Anlene berbeda, yaitu masing-masing 2,5 dan 10. Hasil uji tersebut diperkuat oleh hasil analisis Fishbein terhadap kedua atribut label yang mempunyai perbedaan masing-masing 0,98 untuk Hilo dan 1,27 untuk Anlene.

Perbedaan pada hasil uji Wilcoxon dan Analisis Fishbein mengindikasikan bahwa label produk susu Hilo lebih rendah dibandingkan dengan label susu Anlene, sehingga tingkat kepentingan atribut label pada susu Hilo menurut pendapat konsumen lebih tinggi, yaitu Hilo sebesar $17,5 \%$ dan Anlene sebesar $15 \%$.

\section{Implikasi pada Harga}

Hasil penelitian mengenai sikap konsumen pada atribut harga susu bubuk Hilo dan Anlene masing-masing sebesar 1,19 dan 1,36. Sikap konsumen pada atribut harga Anlene lebih kuat dibandingkan merek Hilo, hal tersebut disebabkan karena konsumen mengetahui bahwa harga susu Anlene lebih murah dibandingkan dengan susu Hilo, sedangkan hasil uji Wilcoxon menyebutkan bahwa sikap konsumen terhadap atribut rasa susu bubuk Hilo dan Anlene sama, yaitu masing-masing 2,5 dan 6. Hasil tersebut menunjukkan bahwa Anlene lebih tinggi dari pada Hilo, hal tersebut dibuktikan oleh:

a) Faktor yang menjadi pertimbangan konsumen terhadap pembelian susu Anlene yaitu harga sebesar 7,5\%, dibandingkan susu Hilo sebesar $5 \%$.

b) Tingkat kepentingan atribut harga susu Anlene mencapai $50 \%$ dibandingkan susu Hilo sebesar $30 \%$.

c) Harga susu Anlene yaitu Rp 40.600/kg dan lebih murah bila dibanding susu Hilo Rp 192.500/kg, selisih keduanya yaitu Rp 51.900 .

Berdasarkan kondisi tersebut, maka strategi yang dapat dilakukan perusahaan Hilo adalah mengurangi biaya produksi, sehingga harga jual per unit Hilo tidak terlalu mahal. Strategi yang lain bisa 
berupa penambahan jumlah produksi, hal tersebut diharapkan mampu mengurangi beban biaya produksi.

\section{Implikasi pada Promosi}

Hasil penelitian mengenai sikap konsumen pada atribut promosi susu bubuk Hilo dan Anlene masing-masing sebesar 0,88 dan 0,22. Sikap konsumen pada merek Hilo lebih kuat dibandingkan merek Anlene, yaitu selisih 0,66. Pernyataan tersebut juga diperkuat dengan hasil uji Wilcoxon dengan beda masing-masing 2,5 dan 8,5.

Rendahnya sikap konsumen pada promosi susububuk Anlene juga dibuktikan oleh:

a) Tingkat kepentingan atribut menurut konsumenterhadap promosi susu Hilo sebesar 7,5\%, dan lebih tinggi (5\%) dibandingkan susu Anlene sebesar $2,5 \%$.

b) Norma subyektif konsumen yang terdiri dari nilai keyakinan dan nilai motivasi dari lingkungan sosial konsumen terhadap pembelian susu Anlene lebih tinggi dibandingkan susu Hilo, yaitu masing-masing sebesar 2,18 dan 2,13. Hal tersebut menunjukkan bahwa lingkungan sosial berpengaruh terhadap pembelian susu Hilo dan Anlene.

\section{Kesimpulan}

Berdasarkan hasil pembahasan, maka dapat diambil beberapa kesimpulan antara lain sebagai berikut:

1. Sikap konsumen terhadap atribut susu bubuk tinggi kalsium merek Hilo dan Anlene memiliki nilai positif, yaitu masing-masing 4,93 dan 4,73. Nilai atribut terendah pada susu Hilo ialah rasa sebesar 0,75 dan nilai atribut tertinggi ialah harga sebesar 1,19. Nilai atribut terendah pada susu Anlene ialah promosi sebesar 0,22 dan nilai atribut tertinggi ialah harga sebesar 1,36.

2. Lingkungan sosial konsumen berpengaruh pada norma subyektif konsumen dalam melakukan pembelian susu Hilo dan Anlene yaitu masingmasing 2,13 dan 2,18, namun variabel yang paling dominan adalah keluarga. Hal tersebut karena keputusan konsumsi keluarga dalam membeli produk melibatkan setidaknya beberapa peranan. Peranan tersebut bisa dipegang oleh suami, istri, anak, kakak, adik, dan anggota keluarga lainnya.

3. Terdapat perbedaan sikap konsumen terhadap atribut rasa, label dan promosi pada merek susu Hilo dan Anlene, namun tidak terdapat perbedaan pada atribut merek dan harga pada kedua susu bubuk tersebut.

\section{Saran}

Berdasarkan hasil penelitian tentang sikap konsumen terhadap susu bubuk berkalsium tinggi dengan menggunakan multi-atribut model dan norma subyektif model, maka saran yang perlu diupayakan adalah langkah-langkah sebagai berikut:
1. Atribut terendah pada susu Anlene menurut konsumen ialah promosi, sedangkan Anlene memiliki norma subyektif model yang tinggi. Hal tersebut menunjukkan bahwa faktor tenaga penjual berpengaruh terhadap pembelian susu, sehingga saran yang tepat ialah menggunakan tenaga penjual sebagai media promosi untuk penjualan produk susu bubuk berkalsium tinggi. Penggunaan tenaga penjual sebagai media promosi juga akan lebih menghemat biaya promosi yang dikeluarkan perusahaan.

2. Atribut terendah pada susu Hilo ialah rasa, sehingga tingkat kepentingan atribut menurut konsumen terhadap rasa susu Hilo hanya sebesar 5\%, dengan demikian perusahaan hendaknya lebih memperhatikan cita rasa dan kekentalan susu.

3. Penlitian ini merupakan penelitian yang bermanfaat untuk banyak kalangan, baik pelajar, perusahaan maupun pengamat bisnis. Namun pada penelitian selanjutnya diharapkan dapat menambhakan beberapa jenis merek susu berkalsium tinggi yang sekarang banyak berkembang di masyarakat.

\section{Daftar Pustaka}

[1] Kottler, P. 1997. Manajemen Pemasaran: Analisis, Perencanaan, Implementasi \& Kontrol. Edisi IX. Prenhallindo. Jakarta.

[2] Engel, F., James, R., Blackwell, D., Paul, W., Miniard. Consumer Behaviour $8^{\text {th }}$ Edition. 2001. Dryden Press. Hourcout Brace Collage Publisher.

[3] Fishbein, M. \& Ajzeen, I. 1975. Belief, Attitude, Intention \& Behavior: An Introduction to Theory \& Research. Addison Wesley Publishing Company. New York.

[4] Wilkie, F. \& Kemins, M. 1990. An Empirical Investigation of Consumer Memory, Attiutude \& Perception Toward Pioner \& Follower Brand. Journal of Marketing. Boston.

[5] Ginter, J., L,. 1974. An Experimental Investigation of Attitude Change and Choice of New Brand.Journal of Marketing Research 11 Februari.

[6] Istiana, L., Syahlani, S.P., dan Nurtini, S. 2006. Pengaruh Sikap, Norma Subyektif \& Kontrol Keperilakuan Terhadap Niat \& Perilaku beli Produk Susu UHT. Jurnal IImiah - IImu Peternakan, UGM. Yogyakarta.

[7] Ibrahim. 2001. Analisis Sikap Konsumen Terhadap Atribut Sabun Mandi Biasa di Kota Yogyakarta: Studi Kasus Sabun Mandi Merek Lux dan Giv. Jurnal IImu Manajemen. Manajemen Pemasaran. UB. Malang. 
[8] Loudon, D.L, \& Bitta, Della, A.J, . 1993. Consumer Behavior: Concept \& Aplicatiom. $4^{\text {th }}$ Edition, Singapore: Mc. Graw Hill Inc, New York.

[9] Sanusi, A. 2012. Metodologi Penelitian Bisnis. Edisi kedua. Penerbit: Salemba Empat. Jakarta.

[10] Kilamanca, M. 2008. Sikap Konsumen terhadap Produk Susu Kedelei di Kota Surakarta. Jurnal Pertanian. Universitas Sebelas Maret. Surakarta.

[11] Praseyo, H. 2007. Analisis Motivasi dan Pertimbangan Pembelian serta Pengaruhnya terhadap Preferensi (Studi Preferensi Konsumen Susu Bubuk Olahan di Kota Malang). Disertasi: Program Doktor Ilmu Pertanian Minat Peternakan. Universitas Brawijaya. Malang.

[12] Retnaningsih $d k k$. 2002. Perilaku Konsumen Susu pada Wanita Dewasa di Jakarta Timur. Jurnal IPB. Bogor.

[13] Hidayat, S. I. 2008. Penilaian Konsumen terhadap Beberapa Atribut Dua Jenis Rokok Produk Sampoerna. Jurnal Riset Ekonomi dan Bisnis. Vol. 8 No. 2. Edisi September 2008.

[14] Supranto, J. 2011. Pengukuran Tingkat Kepuasan Pelanggan (untuk Menaikkan Pangsa Pasar). Penerbit: Rineka Cipta. Jakarta.

[15] Supartono dkk. 2006. Analisis Pengambilan Keputusan Konsumen terhadap Pemilihan Ukuran Kemasan Produk Susu. Jurnal Teknologi Industri Pertanian. UGM. Yogyakarta.

[16] Afriani. 2011. Pengaruh Rangsangan Pemasaran terhadap Perilaku Ibu Rumah Tangga dalam Membeli Susu Bubuk di Kota Jambi. Jurnal Ilmiah - Ilmu Peternakan. Vol. XIV No.2.

[17] Alvita, R. 2008. Hubungan antara Persepsi dan Preferensi Konsumen dalam Kaitannya dengan pengambilan Keputusan Pembelian Susu Bubuk dan Susu Cair. Jurnal Sosial Ekonomi Pertanian. Agribisnis Universitas Brawijaya. Malang.

[18] Hartono, B., Utami, H. D., Amanatullaili, N. 2010. Analisis Faktor-faktor yang Mempengaruhi Konsumen dalam Membeli Produk Susu Pasteurisasi di Kabupaten Kudus. Buletin Peternakan. Vol. 34 (2): $123-130$.

[19] Iriani, Y. dan Barokah M. 2010. Analisis Faktorfaktor yang Mempengaruhi Perilaku Konsumen dalam Pembelian. Jurnal Industri. Universitas Widyagama.

[20] Zahria, I. 2009. Analisis Kepuasan dan Loyalitas Konsumen Susu Bubuk Berkalsium Tinggi Merek Anlene. Skripsi: Program Sarjana
Ekstensi Manajemen Agribisnis. Departemen Agribisnis. Fakultas Ekonomi dan Manajemen. IPB. Bogor.

[21] Sari, D. A. P. 2011. Analisis Tingkat Kepuasan dan Loyalitas Konsumen Produk Keju Merek Kraft di Kota Bogor. Skripsi: Program Sarjana Ekstensi Manajemen Agribisnis. Departemen Agribisnis. Fakultas Ekonomi dan Manajemen. IPB. Bogor. 